\title{
COLONOSCOPIC EXAMINATION PROFILE AT THE UKI HOSPITAL, EAST JAKARTA FROM JANUARY 2014 - JULY 2015
}

\author{
Tiroy Sari B. Simanjuntak ${ }^{1}$ 凹 \\ ${ }^{1}$ Medical Faculty, Universitas Kristen Indonesia, Jakarta, Indonesia
}

Received 18 March 2021

Accepted 15 April 2021

Published 30 April 2021

Corresponding Author

Tiroy Sari B. Simanjuntak, tiroy.si

manjuntak@uki.ac.id

DOI $10.29121 /$

granthaalayah.v9.i4.2021.3865

Funding: This research received no specific grant from any funding agency in the public, commercial, or not-for-profit sectors.

Copyright: (C) 2021 The Author(s). This is an open access article distributed under the terms of the Creative Commons Attribution License, which permits unrestricted use, distribution, and reproduction in any medium, provided the original author and source are credited.

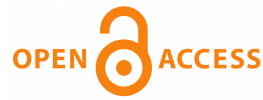

\section{ABSTRACT}

Colonoscopy is a procedure, which is done using a Colonoscope. The technique implemented in evaluating the colon: Picture of the colon, derived from the computed tomography or magnetic resonance imaging, is processed (reconstructed) by the computer to reveal colon lumen in 3D. Colonoscopy is used to diagnose diseases found in the large intestine; however, not all kinds of ailments in the large intestine can be diagnosed by colonoscopy. This study aims to determine the colonoscopy procedure profile in UKI Hospital East Jakarta from 2014 to July 2015. The design used by this research is a descriptive study, which is retrospective to the population of patients that have had a colonoscopy in UKI Hospital from January 2014 to July 2015. This study reveals the colonoscopy procedure profile at UKI Hospital, East Jakarta from January 2014 to July 2015: the most dominant age of the patients receiving colonoscopy is between 50 and 59. Patients are males of Batak ethnicity with a background of high school education. These males' main symptom is abdominal pain, which leads to colitis infection as the primary diagnosis. This study shows that patients who have the colonoscopy done upon them are patients with the age span of 50-59. Most are males due to the factor of lifestyle and stress condition. Background of the patients is working males with high school diplomas. The main complaint found among these patients is abdominal pain. Colitis infection is found to be the primary diagnosis among them.

Keywords: Colonoscopy, Colitis, Colon Ca, Hematochezia

\section{INTRODUCTION}

Gastrointestinal endoscopy is a technique in the field of gastro-enterologyhepatology to view the condition in the upper tract directly (SCBA), called an esophagogastroduodenoscopy (EGD) and the lower gastrointestinal tract is called a colonoscopy, and the dense pancreohepatobiliary organ tract is called ERCP (endoscopic retrograde cholangiopancreatography) using an endoscope. With 
this endoscopic examination, gastrointestinal disorders such as the oesophagus, stomach, duodenum, jejunum, ileum, colon, biliary tract, pancreas, and liver can be detected more easily and precisely. Colonic endos examination is more accurate than radiographs Levin et al. (2008); Spada et al. (2014) Colonoscopy is an examination with a colonoscopy. Imaging techniques for colon examination; A cross-sectional view of the colon, obtained from computed tomography or magnetic resonance imaging, is placed (reconstructed) by a computer for the colonic lumen in three dimensions Clough et al. (2012). Colonoscopy with flexible optical fibres makes it possible to view and biopsy lesions along the colon length. A small video camera attached to the colonoscopy, which has a length from 48 inches $(125 \mathrm{~cm})$ to 72 inches $(183 \mathrm{~cm})$ Jeong et al. (2013). Indications for colonoscopy are gastrointestinal bleeding, chronic diarrhoea, suspected inflammatory bowel disease (IBD), malignancy survey, interventional therapy: polypectomy, foreign body extraction, dilation. stricture, cauterization Belsha et al. (2016); Favuzza and Delaney (2013); Gerson et al. (2009); Sheen et al. (2019). One example of ulcerative colitis. The occurrence of ulcerative colitis worldwide has been increasing over the last few years.

In contrast to developed countries from North America and Western Europe, where the incidence of ulcerative colitis has plateaued or even decreased, da Silva et al. (2014); Molodecky et al. (2012). Publications show that the number of cases has increased in developing countries, such as in Latin America, Asia and Eastern Europe Dhanwal et al. (2011); Haggard and Kaufman (2008) although there are still differences and Prevalence in various regions of the world. The incidence rate of ulcerative colitis can vary from 0.5 to 31.5 per 100,000 people each year, depending on the population studied Fernández et al. (2015). The Prevalence of ulcerative colitis incidence in developing countries is low; for example, in Asian countries, there are 5.3-63.6 per 100,000 people Shivashankar et al. (1970); Welty et al. (2020). Meanwhile, in North America, 37.5-238 per 100,000 people.16,17 Based on the above background, the researcher wanted to examine the profile of the colonoscopy examination at the UKI Hospital, East Jakarta for the period from January 2014 to July 2015. Based on the description In the background of the above problems, research questions can be formulated as follows: a) what diseases are indicated using colonoscopy supporting examinations at UKI Hospital, East Jakarta? b) what is the Prevalence of diseases indicated using colonoscopic investigations at the UKI Hospital, East Jakarta during the period January 2014-July 2015? Furthermore, c) what is the procedure for a colonoscopy?

\section{THEORETICAL REVIEW}

The large intestine or colon is in the form of a hollow muscular tube about $1.5 \mathrm{~m}$ long extending from the cecum to the anal canal. The large intestine diameter is about $6.5 \mathrm{~cm}$, but the closer the anus is, the smaller it is. The large intestine is divided into cecum, colon, and rectum. The cecum has an ileocecal valve and an appendix attached 
to the end of the cecum. The cecum occupies about the first two or three inches of the colon. The ileocecal valve controls the flow of the chymus from the ileum into the cecum. The colon is further divided into ascending, transverse, descending, and sigmoid colon. The place where the colon forms sharp bends, namely on the right and upper left abdomen, is called the hepatic flexure and splenic flexure, respectively. The sigmoid colon is at the level of the iliac crest and forms an S-shaped indentation E. et al. (2019); Nasr et al. (2015). The lower indentation bends to the left as the sigmoid colon joins the rectum. This position affects the force of gravity to help drain water from the rectum to the sigmoid flexure. The last major part of the large intestine is known as the rectum and extends from the sigmoid colon to the anus (estuary to the outside of the body). The last inch of the rectum is referred to as the anal canal and is protected by the external and internal anal sphincter muscles. The length of the rectum and anal canal is about $15 \mathrm{~cm}$ Levin et al. (2008); Serra-Aracil et al. (2019). The external muscle fibres collect into three longitudinal bands, namely taenia coli. Because these bands are shorter than the rest of the colon, the colon's walls form a protrusion (haustra) between the tenia. Colonic mucosa is devoid of villi. Colon glands are short, secretive inward protrusions of mucous mucus. There are solitary lymph follicles, especially in the cecum and appendix Moulin (2012).

The colon wall consists of four layers: the mucosa, submucosa, external muscular and serosa. The mucosa consists of cylindrical epithelium, intestinal glands, lamina propia and muscular mucosa Petrinec et al. (2005). The large intestine does not have plica and villi, so the mucosa appears flatter than that of the small intestine Barzat et al. (2014). The submucosa underneath contains connective tissue cells and fibres, various blood vessels and nerves. Both layers of muscle in the external musculus are visible. Both the transverse colon and the sigmoid colon are attached to the body wall by the mesentery. Therefore, the serosa becomes the outermost layer of these two parts of the colon. Inside the mesentery, there are loose connective tissue, fat cells, blood vessels and nerves. The primary function of the colon is the absorption of water and electrolytes from the chymus to form solid faeces and the accumulation of faecal material until it can be excreted, the colon converts $1000-2000 \mathrm{~mL}$ of isotonic chemistry which enters daily from the ileum into a semisolid stool with a volume of about 200-250mL Moulin (2012); Palmer et al. (2017). Most of the large intestine absorption occurs in the mid-proximal colon, whereas the distal colon serves primarily as a storage area Palmer et al. (2017).

The large intestine is divided into cecum, colon, and rectum. The last major part of the large intestine is known as the rectum and extends from the sigmoid colon to the anus (estuary to the outside of the body). The last inch of the rectum is referred to as the anal canal and is protected by the external and internal anal sphincter muscles. The rectum and anal canal length is approximately $15 \mathrm{~cm}$. 2 The rectum begins at the level of the II or III sacral vertebrae and ends at the pelvic floor which is penetrated by the anal canal. The rectum has two arcs in the sagittal plane: the dorsal convex sacral flexure and the ventral convex perineal flexure. Unlike the colon, the muscular 
layer (tunica muscularis) of the rectum consists not only of a circular layer (stratum circular) but also a continuous longitudinal layer (stratum longitudinal) Hanafy et al. (2020). The histology of the rectum is similar to that of the colon. The lumen surface epithelium is lined by cylindrical layer cells with limbus striatus and goblet cells. The intestinal glands, adipose cells, and lymphoid nodules in the lamina propria are similar to those in the colon. The intestinal glands are more extended, denser, and filled with goblet cells. Under the lamina propria are the mucous muscular. Longitudinal folds in the upper rectum and temporary colon. This fold has a central submucosa lined by mucosa. Permanent longitudinal folds (rectal columns) are present in the lower rectum and anal canal. Taenia coli in the colon continues into the rectum, where the external muscularis is composed of layers of outer circular and longitudinal smooth muscle. Between the two layers of smooth muscle is the parasympathetic ganglion of the myenteric plexus (Auerbach). Adventist covers part of the rectum, and serosa covers the rest. Many vessels are found in the submucosa and adventitia Valero et al. (2019).

The propulsion of feces into the rectum distends the rectal wall and stimulates the defecation reflex. The external and internal anal sphincter controls defecation. The internal sphincter is controlled by the autonomic nervous system, while the voluntary nervous system controls the external sphincter. The defecation reflex is integrated into the second and fourth sacral segments of the spinal cord. Parasympathetic fibres reach the rectum via the pelvis's splanchnic nerve and cause rectal contraction and the internal sphincter's relaxation. When the stretched rectum contracts, the levator ani muscle relaxes, causing the anorectal angle and annulus to disappear. The internal and external sphincter muscles relax when the anus is pulled up above the faecal mass's height. The rectum and anus are the sites of some of the most common diseases in humans Levin et al. (2008).

Colonoscopy is an examination with a colonoscopy. Imaging techniques for colon examination; Cross-sectional views of the colon, obtained from computed tomography or magnetic resonance imaging, are processed (reconstructed) by a computer to show the colonic lumen in three dimensions Clough et al. (2012). Colonoscopy with flexible fibre optics allows viewing and biopsy of lesions along the large intestine Levin et al. (2008). Flexible colonoscopy was first used since October 1973 by Hilmy et al. Spada et al. (2014). Radiographic examination with a barium enema is a standard examination to detect colonic disorders. It is essential to prepare or cleanse the colon before the examination to be carried out carefully Serra-Aracil et al. (2019). Preparations made for colonoscopy were 2 days before the patient was admitted to hospitalization. The first day - laboratory preparations in the form of routine blood tests, clotting period, bleeding period, EKG, and Thorax photos; The second day at 20.00 WIB the patient drank the first fleet phosphosoda $45 \mathrm{ml}$ diluted in $150 \mathrm{cc}$ of water, drunk at once, then fasted to eat but drank as much water or as much as the patient could; The third day-at 05.00 in the morning drink the second phosphosoda flees $45 \mathrm{ml}$ diluted in $150 \mathrm{cc}$ of water drunk at once then drink water as much 
as possible until the action is carried out; The nurse must observe the patient for a successful bowel movement at the time of the procedure; Inpatient installation; ICU; Laboratory; Radiology; and Electromedical.

Indications for colonoscopy are gastrointestinal bleeding, chronic diarrhoea, suspected inflammatory bowel disease (IBD), the survey of malignancy, interventional therapy: polypectomy, foreign body extraction, stricture dilatation, cauterization Belsha et al. (2016); Gerson et al. (2009); Jovanovic et al. (2011); Yano and Yamamoto (2009). Colonoscopy should not be performed if the patient is unwilling to give informed consent, the patient is uncooperative, inadequate sedation, known or suspected colonic perforation, severe toxic megacolon and fulminant colitis, the patient is clinically unstable, inadequate bowel preparation Bhagatwala et al. (2015); Cappell (2008). Gastrointestinal bleeding can originate from any part of the gastrointestinal tract, from the mouth to the anus. Practically divided into upper gastrointestinal bleeding if the bleeding originates from the proximal traits ligament (from the mouth to the duodenum) and lower gastrointestinal bleeding if the bleeding originates distal to the site. Hematoskezia, namely the discharge of fresh blood through the rectum, generally indicates the source of bleeding that is located distal to the Treitz ligament. However, because blood has to remain in the intestines for approximately 8 hours to produce melena, rapid bleeding into the oesophagus, stomach, or duodenum can also result in metascience Al-Ghabra and Mamoli (2014).

Hematochezia is a clinical manifestation of lower gastrointestinal bleeding, bowel movements containing fresh blood with or without blood clots. It occurs mainly from bleeding in the rectum or the colon's left side (rectum, sigmoid and descending colon). Another form is maroon stool's appearance, a red heart / dark red colour, usually bleeding in the right colon (ileocaecal and ascending colon). At first glance, the maroon stool looks like melena, so it must be observed. It should also be borned in mind that haematoscience can also result from SCBA haemorrhage, particularly the duodenum, where the blood is not exposed to gastric acid or excessive blood counts Braicu et al. (2016).

The colon (including the rectum) is the most common site of gastrointestinal malignancy. Colon cancer is the third leading cause of all cancer deaths in the United States, in both men and women. Colon cancer is usually a disease that occurs in old organs, with a peak indication at 60-70. Colon cancer is rare at age 40 years, except in people who have a history of ulcerative colitis or familial polyposis. Men and women were attacked in equal numbers. About $60 \%$ of all colon cancers occur in the rectosigmoid region to be palpable on rectal examination or seen on sigmoidoscopy. The cecum and ascending colon are the next most frequently affected sites. The transverse colon and flexure are the least affected Levin et al. (2008). Colitis is an acute or chronic inflammation of the colon, which based on its cause can be classified as follows Marín et al. (2013): a) Infectious colitis, for example, shigellosis (bacillary dysentery), tuberculous colitis, amoebic colitis, pseudomembranous coli- 
tis, colitis due to viruses/bacteria/other parasites, and b) Non-infectious colitis, for example, ulcerative colitis, Chrohn's disease, radiation colitis, ischemic colitis, microscopic colitis, non-specific colitis (simple colitis).

\section{RESEARCH METHODOLOGY}

This research is a retrospective descriptive study to see the colonoscopy examination profile at the UKI Hospital from January 2014 to July 2015. A sampling of medical records was carried out in the medical records section of the UKI Hospital. The sampling of medical records was carried out on 10 August - 20 October 2015. This study's population was patients who had undergone a colonoscopy examination at the UKI Hospital from January 2014 to July 2015. The sample taken to support this study was patients' medical records at the UKI Hospital from January 2014 to July 2015. In this study, the data collected was carried out using secondary data obtained from descriptive medical records at UKI Hospital. Data processing is done through the process of editing, coding, tabulating, and cleaning. To display the frequency distribution and percentage of each variable in the form of a table or figure. The data obtained is then processed using the SPSS program, and submitted in distribution tables and descriptions.

\section{RESULT AND DISCUSSION}

The characteristics of this study include age, gender, ethnicity, occupation, education.

\begin{tabular}{|c|c|c|c|c|c|}
\hline \multicolumn{6}{|c|}{ Age Category } \\
\hline & & Frequency & Per cent & Valid Percent & Cumulative Percent \\
\hline \multirow[t]{8}{*}{ Valid } & $20-29$ & 3 & 5,4 & 5,4 & 5,4 \\
\hline & $30-39$ & 6 & 10,7 & 10,7 & 16,1 \\
\hline & $40-49$ & 9 & 16,1 & 16,1 & 32,1 \\
\hline & $50-59$ & 15 & 26,8 & 26,8 & 58,9 \\
\hline & $60-69$ & 14 & 25,0 & 25,0 & 83,9 \\
\hline & $70-79$ & 8 & 14,3 & 14,3 & 98,2 \\
\hline & $80-89$ & 1 & 1,8 & 1,8 & 100,0 \\
\hline & Total & 56 & 100,0 & 100,0 & \\
\hline
\end{tabular}

Based on Table 1 , it shows that the age group is mostly found in the $50-59$ years age group as many as 15 cases (26.8\%), then in the 60-69 age group as many as 14 cases $(25.0 \%)$, in the $40-49$ years as many as 9 cases $(16.1 \%)$, then in the $70-79$ year age group as many as 8 cases (14.3\%), in the 30-39 year age group as many as 6 cases (10.7\%), in the age group $20-29$ years as many as 3 cases (5.4\%), and the least in the 80-89 year age group was 1 case (1.8\%). 


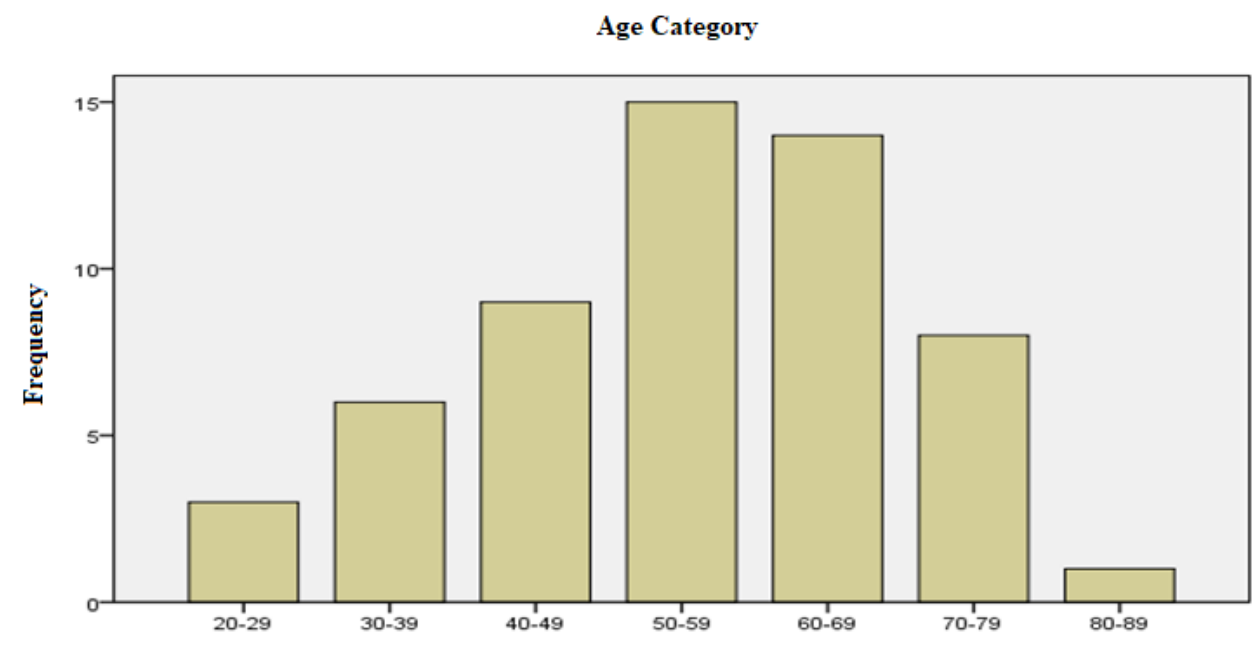

Figure 1 The Frequency Distribution of Patients by Age Category

Based on the Colonoscopic Examination Profile at the UKI Hospital, East Jakarta for the period January 2014 - July 2015 with $\mathrm{N}=56$, it was found that the most age groups were found in the 50-59 year age group as many as 15 cases $(26.8 \%)$.

Table 2 The Frequency Distribution of Patients by Gender

\begin{tabular}{lccccc}
\hline \multicolumn{1}{l}{ Gender } & & & & & \\
\multirow{2}{*}{ Valid } & Male & 31 & 55,4 & 55,4 & 55,4 \\
& Female & 25 & 44,6 & 44,6 & 100,0 \\
& Total & 56 & 100,0 & 100,0 & \\
\hline
\end{tabular}

hows that the sex with the most frequency was male, namely 31 patients $(55.4 \%)$, while the lowest was female, 25 patients (44.6\%).

\section{Gender}

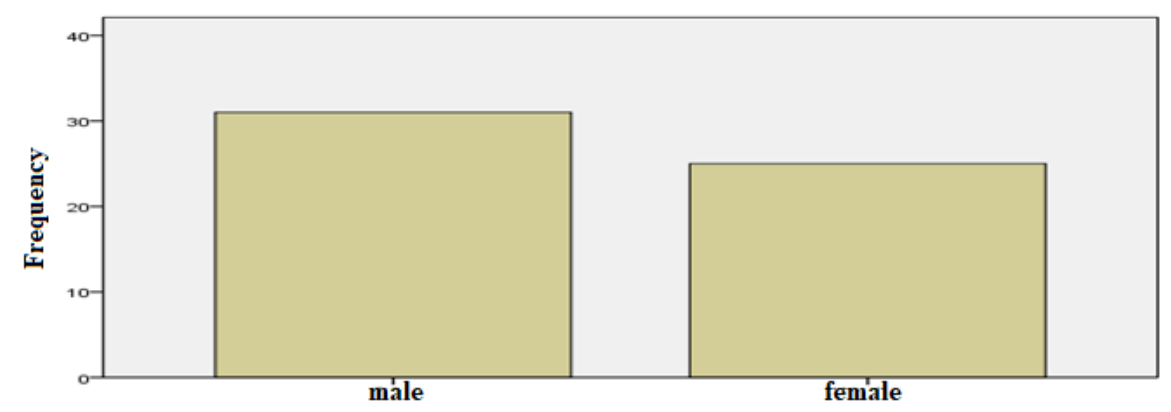

Figure 2 The Frequency Distribution of Patients by Gender 
Based on the Colonoscopic Examination Profile at the UKI Hospital, East Jakarta for the period January 2014 - July 2015 with $\mathrm{N}=56$, it was found that the largest gender was male, namely 31 patients (55.4).

Table 3 The Frequency Distribution of Patients by Ethnicity

\begin{tabular}{|c|c|c|c|c|c|}
\hline \multicolumn{6}{|c|}{ Respondent's Ethnicity } \\
\hline & & Frequency & Per cent & Valid Percent & Cumulative Percent \\
\hline \multirow[t]{8}{*}{ Valid } & N/A & 9 & 16,1 & 16,1 & 16,1 \\
\hline & Bataknese & 30 & 53,6 & 53,6 & 69,6 \\
\hline & Javanese & 11 & 19,6 & 19,6 & 89,3 \\
\hline & Malukunese & 2 & 3,6 & 3,6 & 92,9 \\
\hline & Torajanese & 1 & 1,8 & 1,8 & 94,6 \\
\hline & Ambonese & 2 & 3,6 & 3,6 & 98,2 \\
\hline & Sundanese & 1 & 1,8 & 1,8 & 100,0 \\
\hline & Total & 56 & 100,0 & 100,0 & \\
\hline
\end{tabular}

hows that the ethnic group with the most number is the Batak ethnic group with 30 patients (53.6\%), followed by the Javanese with 11 patients $(19.6 \%)$, nine patients with unknown ethnicity (16.1\%), Then the Ambonese and Maluku ethnic groups have the same number of 2 patients (3.6\%), and the least are the Toraja and Sundanese who also have the same number of 1 patient $(1.8 \%)$.

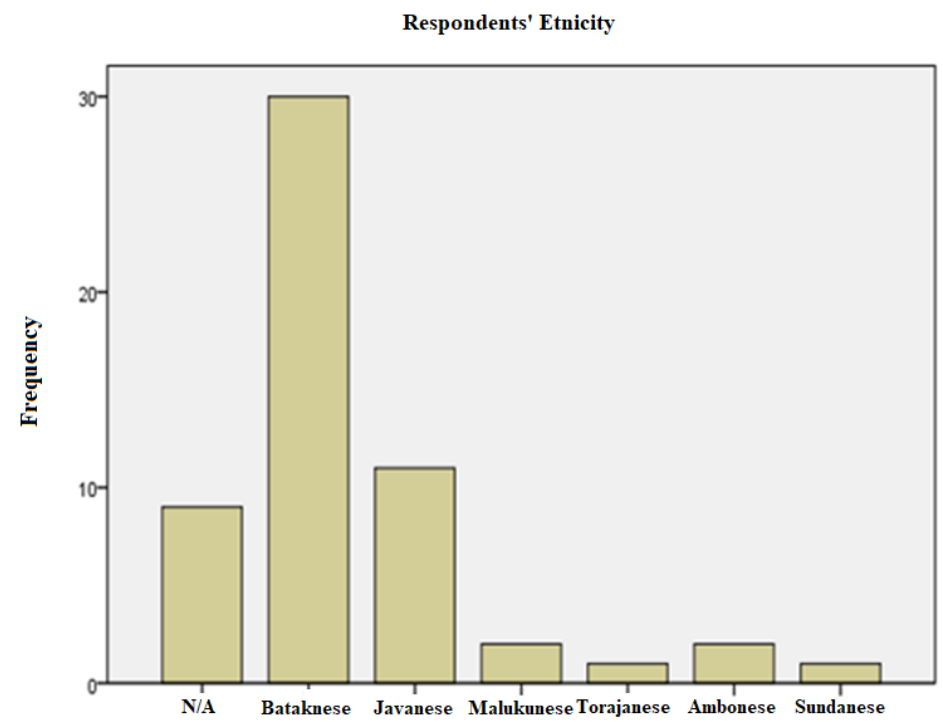

Figure 3 The Frequency Distribution of Patients by Ethnicity

Based on the Colonoscopic Examination Profile at the UKI Hospital, East Jakarta for the period January 2014 - July 2015 with $\mathrm{N}=56$, it was found that the most ethnic group was the Batak tribe, namely 30 patients (53.6\%). 
Table 4 The Frequency Distribution of Patients by Occupation

\begin{tabular}{|c|c|c|c|c|c|}
\hline \multicolumn{6}{|c|}{ Respondent Profession } \\
\hline & & Frequency & Per cent & Valid Percent & Cumulative Percent \\
\hline \multirow[t]{5}{*}{ Valid } & N/A & 3 & 5,4 & 5,4 & 5,4 \\
\hline & Work & 34 & 60,7 & 60,7 & 66,1 \\
\hline & Jobless & 14 & 25,0 & 25,0 & 91,1 \\
\hline & Retired & 5 & 8,9 & 8,9 & 100,0 \\
\hline & Total & 56 & 100,0 & 100,0 & \\
\hline
\end{tabular}

hows that the occupation with the most frequency was working patients, namely 34 patients $(60.7 \%)$, followed by 14 patients $(25.0 \%)$ who did not work, then retired five patients $(8.9 \%)$, while the least was unknown, namely three patients $(5.4 \%)$.

Respondents' Profession

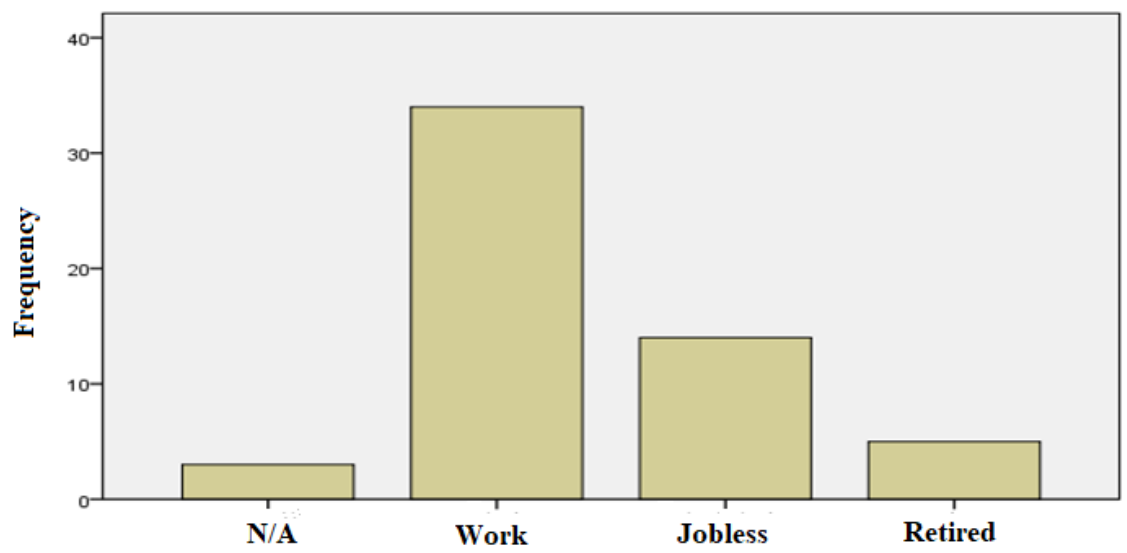

Figure 4 TheFrequency Distribution of Patients by Occupation

Based on the Colonoscopic Examination Profile at the UKI Hospital, East Jakarta for the period January 2014 - July 2015 with $\mathrm{N}=56$, it was found that the most frequent occupations were working patients, namely 34 patients $(60.7 \%)$.

Table 5 The Frequency Distribution of Patients Based on Education

\begin{tabular}{cccccc}
\hline \multicolumn{2}{c}{ Respondents' Education } & & & & \\
& & Frequency & Per cent & Valid Percent & Cumulative Percent \\
\hline \multirow{2}{*}{ Valid } & Elementary & 3 & 5,4 & 5,4 & 5,4 \\
\cline { 2 - 5 } & Senior High School & 38 & 67,9 & 67,9 & 73,2 \\
\hline & Bachelor & 15 & 26,8 & 26,8 & 100,0 \\
\hline & Total & 56 & 100,0 & 100,0 & \\
\hline
\end{tabular}

hows that the most patient education at high school graduation is 38 patients (67.9\%), then graduate graduates are 15 patients $(26.8 \%)$, and the least number of 
elementary school graduates is three patients (5.4\%) ).

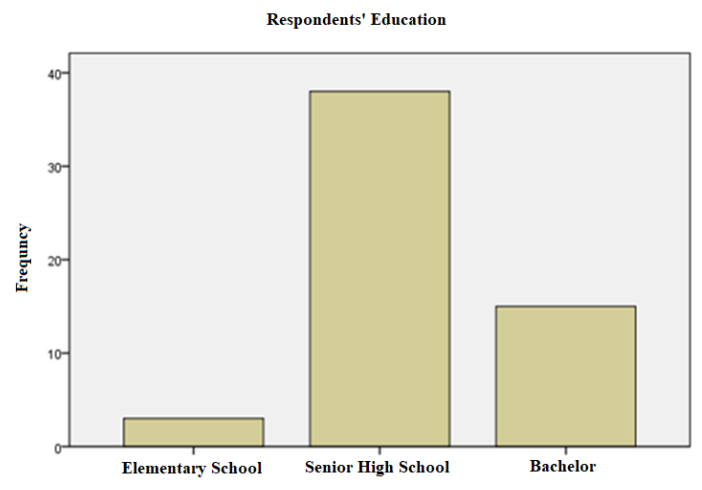

Figure 5 The Frequency Distribution of Patients Based on Education

Based on the Colonoscopic Examination Profile at the UKI Hospital, East Jakarta for the period of January 2014 - July 2015 with $N=56$, it was found that most patients graduated from high school, namely 38 patients $(67.9 \%)$.

With a good history and physical examination, we can find out what the patient's main complaint is, by taking anamnesis alone, more than $60 \%$ of internal disease diagnoses can be confirmed. With a physical examination, the diagnosis can be confirmed as much as $20 \%$. Then followed by investigations to further confirm a definite diagnosis of a disease.

Table 6 The Frequency Distribution of Patients Based on Patient's Main Complaints

\begin{tabular}{|c|c|c|c|c|c|}
\hline \multicolumn{6}{|c|}{ Main Complaint } \\
\hline & & Frequency & Per cent & Valid Percent & $\begin{array}{c}\text { Cumulative } \\
\text { Percent }\end{array}$ \\
\hline \multirow[t]{12}{*}{ Valid } & $\begin{array}{l}\text { Stomach } \\
\text { Bloating }\end{array}$ & 1 & 1,8 & 1,8 & 1,8 \\
\hline & Stomach Pain & 25 & 44,6 & 44,6 & 46,4 \\
\hline & $\begin{array}{l}\text { Bloody bowel } \\
\text { movements }\end{array}$ & 13 & 23,2 & 23,2 & 69,6 \\
\hline & Diarrhoea & 4 & 7,1 & 7,1 & 76,8 \\
\hline & Low back pain & 2 & 3,6 & 3,6 & 80,4 \\
\hline & Fever Chills & 1 & 1,8 & 1,8 & 82,1 \\
\hline & $\begin{array}{c}\text { Difficult to } \\
\text { defecate }\end{array}$ & 6 & 10,7 & 10,7 & 92,9 \\
\hline & $\begin{array}{l}\text { Small dung like } \\
\text { goat droppings }\end{array}$ & 1 & 1,8 & 1,8 & 94,6 \\
\hline & $\begin{array}{c}\text { To do a } \\
\text { colonoscopy }\end{array}$ & 1 & 1,8 & 1,8 & 96,4 \\
\hline & Heartburn & 1 & 1,8 & 1,8 & 98,2 \\
\hline & $\begin{array}{l}\text { Bleeding per } \\
\text { rectal }\end{array}$ & 1 & 1,8 & 1,8 & 100,0 \\
\hline & Total & 56 & 100,0 & 100,0 & \\
\hline
\end{tabular}


From the patient's history, most patients who undergo colonoscopy are patients who come with complaints of abdominal pain. The data above shows that 25 patients (44.6\%) had complaints of abdominal pain, 13 patients $(23.2 \%)$ had bloody bowel movements, six patients had difficulty defecating (10.7\%), four patients $(7.1 \%)$ had diarrhoea. ), low back pain in 2 patients (3.6\%), then the lowest was flatulence, chills, small bowel movements such as goat faeces, for colonoscopy, heartburn, and bleeding per rectal the same number of 1 patient (1.8).

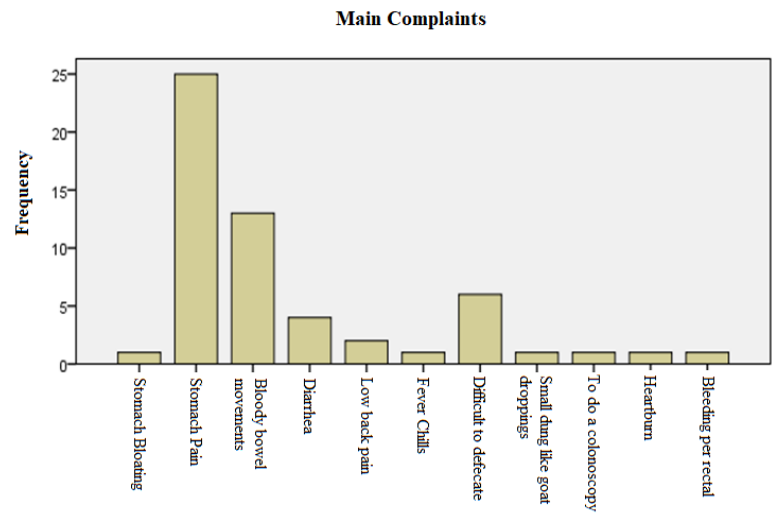

Figure 6 The Frequency Distribution of Patients Based on Patient's Main Complaints

Based on the Colonoscopic Examination Profile at the UKI Hospital, East Jakarta for the period January 2014 - July 2015 with $\mathrm{N}=56$, it was found that the most common complaints were patients who came with abdominal pain, namely 25 patients $(44.6 \%)$. An overview of the patient frequency distribution based on vital signs and physical examination of the patient can be seen in the following figure:

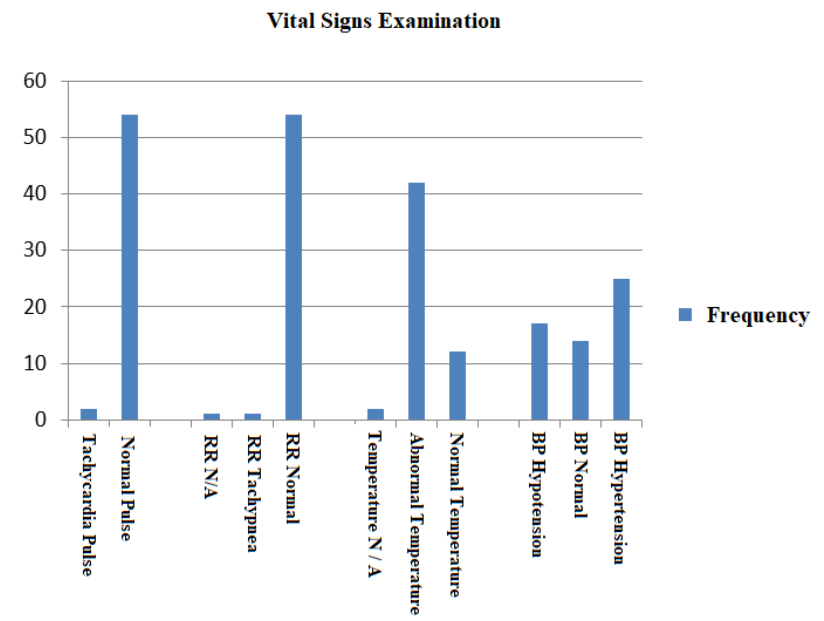

Figure 7 Vital Signs Examination Result 
In this study, it was found that most of the patients' vital signs were within normal limits. Two patients had an abnormal pulse. The patient is experiencing shortness of breath one person. Patients had high BP in 25 people and low BP in 17 people. The patient temperature was mostly abnormal, namely 42 people and normal temperature of 12 people. All patients in the study had compos mentis consciousness. Most of the patient's vital signs indicate that a typical patient is likely not experiencing major complaints from complications of other diseases. Apart from examining the vital signs, the patient also needs an abdominal examination, namely by inspection, palpation, percussion and auscultation of the stomach.

An overview of the frequency distribution of patients based on the results of lab tests can be seen in the following figure:

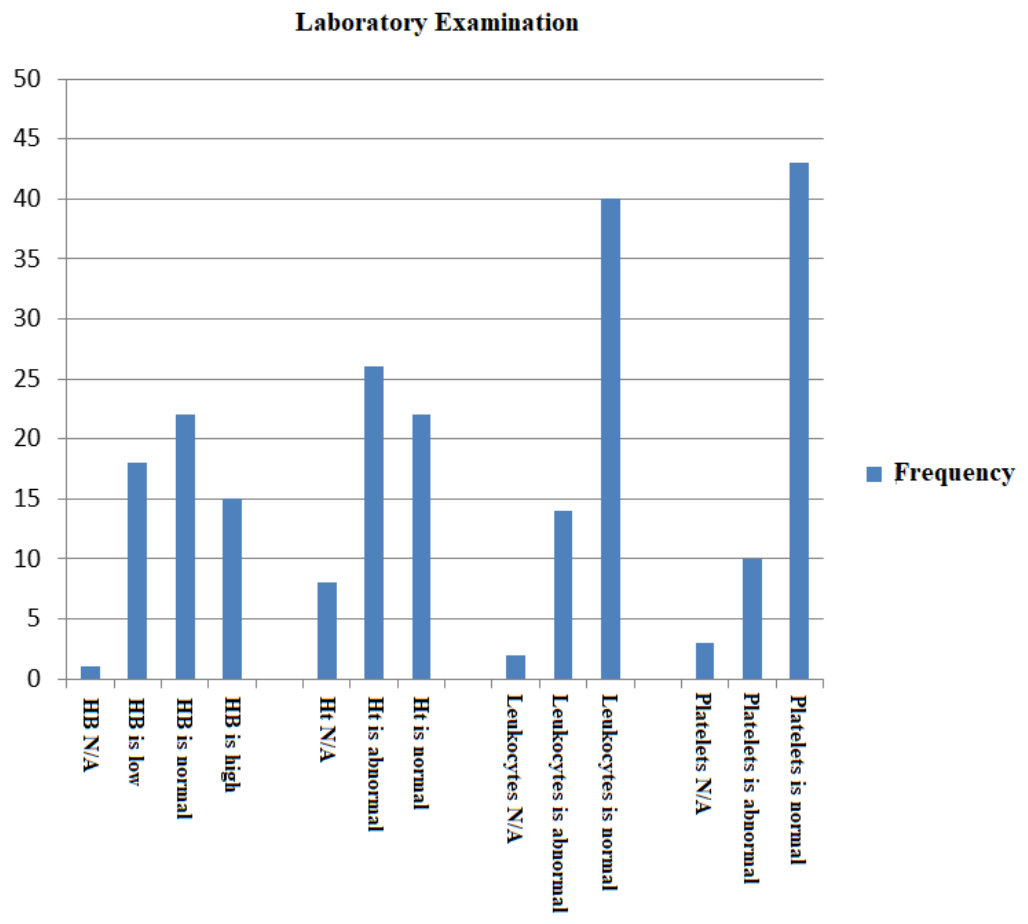

Figure 8 Laboratory Examination Result

This lab examination showed that most of the patients' lab examinations were within normal limits, namely 22 patients, 18 patients with low HB. There were 15 patients with high HB. The low haemoglobin a patient may experience is usually associated with iron deficiency anaemia. Other causes of low Hb include heavy bleeding, hemolysis. There were 26 patients with abnormal hematocrit, 22 patients with normal hematocrit, and eight patients whose data was unknown from this hematocrit examination. From the examination of leukocytes, it can be seen that 40 patients with normal leukocytes are found. Then there were 14 patients with low leukocytes. And unknown results (N / A) in 2 patients. Leukocytes that are above the normal count indicates an infection. From this thrombocyte examination, it can be seen that 43 
patients with normal platelets, ten patients with abnormal platelets. Platelet results are needed to indicate patient status; Decreased platelets (thrombocytopenia) can be found in dengue hemorrhagic fever, as well as anaemia.

An overview of the frequency distribution of patients based on the diagnosis after colonoscopy can be seen in Table 7 below:

Table 7 Clinical Diagnosis Result

\begin{tabular}{|c|c|c|c|c|c|}
\hline \multicolumn{6}{|c|}{ Clinical Diagnosis } \\
\hline & & Frequency & Per cent & $\begin{array}{c}\text { Valid } \\
\text { Percent }\end{array}$ & $\begin{array}{l}\text { Cumulative } \\
\text { Percent }\end{array}$ \\
\hline \multirow[t]{23}{*}{ Valid } & $\mathrm{N} / \mathrm{A}$ & 1 & 1,8 & 1,8 & 1,8 \\
\hline & $\begin{array}{l}\text { Rectosigmoid } \\
\text { colitis }\end{array}$ & 3 & 5,4 & 5,4 & 7,1 \\
\hline & Hematochezia & 3 & 5,4 & 5,4 & 12,5 \\
\hline & Infective Colitis & 25 & 44,6 & 44,6 & 57,1 \\
\hline & Colonic Tumors & 2 & 3,6 & 3,6 & 60,7 \\
\hline & $\begin{array}{l}\text { hematochezia e.c } \\
\text { infective colitis }\end{array}$ & 2 & 3,6 & 3,6 & 64,3 \\
\hline & chronic diarrhoea & 2 & 3,6 & 3,6 & 67,9 \\
\hline & $\begin{array}{l}\text { rectosigmoid area } \\
\text { tumor }\end{array}$ & 2 & 3,6 & 3,6 & 71,4 \\
\hline & rectal tumours & 1 & 1,8 & 1,8 & 73,2 \\
\hline & $\begin{array}{l}\text { ulcerative type of } \\
\text { infective colitis }\end{array}$ & 1 & 1,8 & 1,8 & 75,0 \\
\hline & Choledocholithiasis & 1 & 1,8 & 1,8 & 76,8 \\
\hline & PNC & 1 & 1,8 & 1,8 & 78,6 \\
\hline & $\begin{array}{l}\text { infective colitis w / } \\
\text { haemorrhoidal } \\
\text { hematosis }\end{array}$ & 1 & 1,8 & 1,8 & 80,4 \\
\hline & $\begin{array}{l}\text { irritable bowel } \\
\text { syndrome }\end{array}$ & 1 & 1,8 & 1,8 & 82,1 \\
\hline & $\begin{array}{l}\text { rectosigmoid } \\
\text { tumour }\end{array}$ & 2 & 3,6 & 3,6 & 85,7 \\
\hline & $\begin{array}{l}\text { hematoskezia e.c } \\
\text { susp ca colon }\end{array}$ & 1 & 1,8 & 1,8 & 87,5 \\
\hline & caecum tumour & 1 & 1,8 & 1,8 & 89,3 \\
\hline & susp. Colonic Ca & 2 & 3,6 & 3,6 & 92,9 \\
\hline & $\begin{array}{l}\text { hematoskezia e.c } \\
\text { diverucel sigmoid }\end{array}$ & 1 & 1,8 & 1,8 & 94,6 \\
\hline & $\begin{array}{l}\text { hematochezia e.c } \\
\text { susp malignancy }\end{array}$ & 1 & 1,8 & 1,8 & 96,4 \\
\hline & liver abscess & 1 & 1,8 & 1,8 & 98,2 \\
\hline & $\begin{array}{l}\text { Post laparotomy } \\
\text { exploration a.i } \\
\text { ca.rectosigmoid }\end{array}$ & 1 & 1,8 & 1,8 & 100,0 \\
\hline & Total & 56 & 100,0 & 100,0 & \\
\hline
\end{tabular}

The study results found that after the colonoscopy procedure, the most working diagnoses were caused by infective colitis, namely 25 patients (44.6\%). 


\section{Clinical Diagnosis}

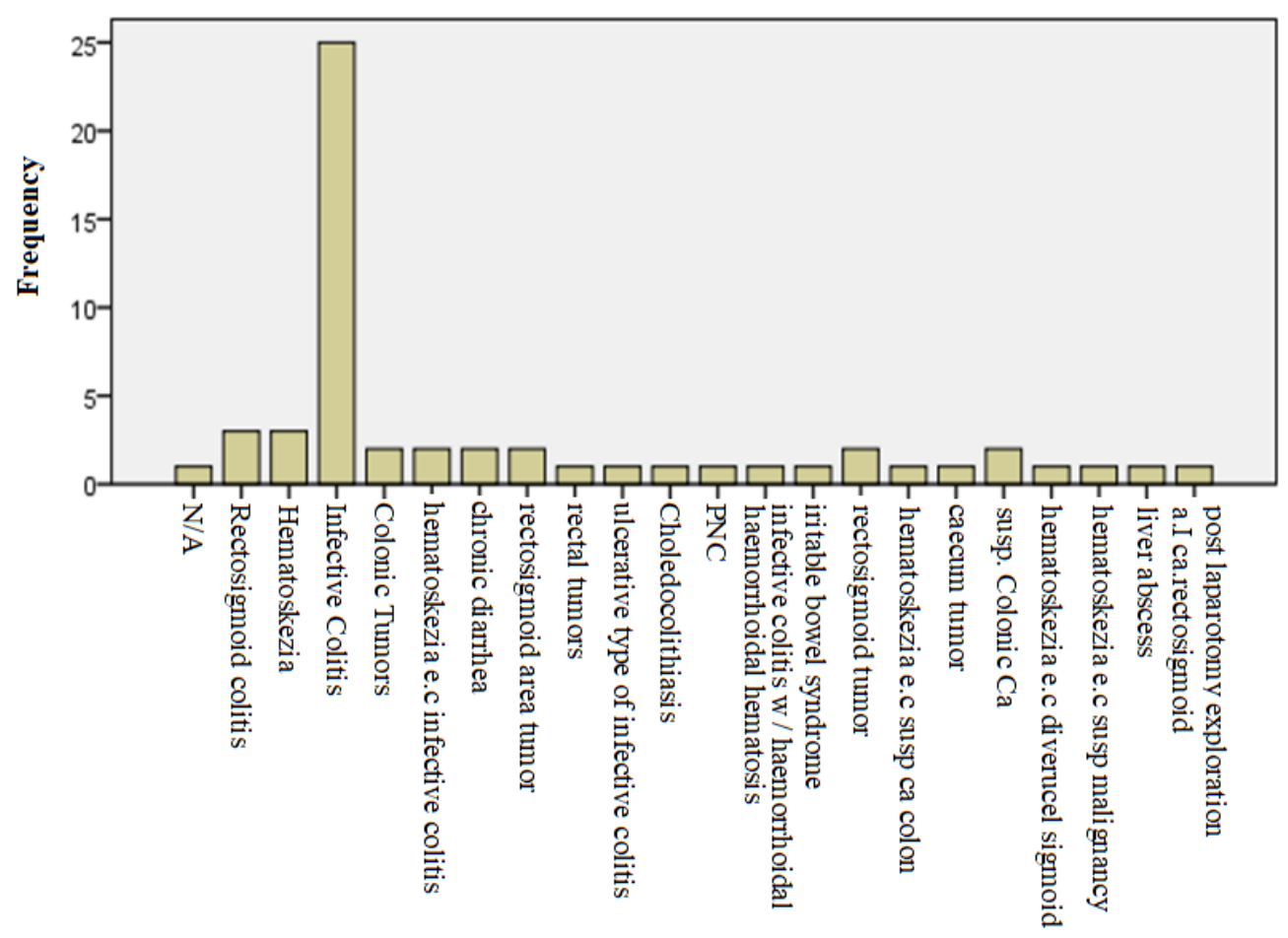

Figure 9 Clinical Diagnosis Result

Based on the Colonoscopic Examination Profile at the UKI Hospital, East Jakarta from January 2014 - July 2015 with $\mathrm{N}=56$, the most clinical diagnosis was infective colitis, namely 25 patients (44.6\%). Colonoscopic Examination Profile at the UKI Hospital, East Jakarta for the period January 2014 - July 2015

\begin{tabular}{llllll}
\hline \multicolumn{7}{l}{ Table 8} & Colonoscopic Examination Profile at the UKI Hospital & \\
\hline No & Category & Result & Fre quency & Sample Total & \% \\
\hline 1 & age (years) & $50-59$ & 15 & 56 & 26,8 \\
\hline 2 & gender & Male & 31 & 56 & 55,4 \\
\hline 3 & tribe & Bataknese & 30 & 56 & 53,6 \\
\hline 4 & profession & Work & 34 & 56 & 60,7 \\
\hline 5 & education & Senior High School & 38 & 56 & 67,9 \\
\hline 6 & main complaint & abdominal pain & 25 & 56 & 44,6 \\
7 & clinical diagnosis & infective colitis & 25 & 56 & 44,6
\end{tabular}

Based on the Colonoscopic Examination Profile at the UKI Hospital, East Jakarta for the period January 2014 - July 2015 with $\mathrm{N}=56$, it was found that the most age was found in the 50-59 years age group as many as 15 cases (26.8\%). Most of the sex was male, namely 31 patients (55.4). The most ethnic group is the Batak tribe, 
which is 30 patients (53.6\%). The occupations with the most frequency were working patients, namely 34 patients (60.7\%). Most patient education was found at a high school graduation, namely, 38 patients $(67.9 \%)$. The main complaint was patients who came with abdominal pain, namely 25 patients (44.6\%). The most clinical diagnosis was infective colitis, namely 25 patients (44.6\%).

\section{CONCLUSION}

Based on the research results of the Colonoscopic Examination Profile at the UKI Hospital, East Jakarta for the period January 2014 - July 2015, it was found: a) From the age profile, most patients who undergo colonoscopy are vulnerable patients aged 50-59 years; b) Most of the patients who undergo colonoscopy are male patients; c) Most of the patients who performed colonoscopy were from the Batak tribe; d) The occupational background of most patients who undergo colonoscopy is working patients; e) The most educational background of patients who undergo colonoscopy are patients with high school graduation; f) The main complaint most often complained of by patients who undergo colonoscopy are patients with abdominal pain, bloody bowel movements, complicated bowel movements, diarrhea; g) The most working diagnosis obtained after colonoscopy is infective colitis; and h) The conclusion obtained from the results of the study is that patients who perform colonoscopy are the most vulnerable patients aged 50-59 years, most of them are male due to gender factors related to lifestyle and stressful conditions. With a working patient background, graduated from high school and the main complaint that is most often felt is abdominal pain. The most common occupational diagnosis is infective colitis.

\section{REFERENCES}

Al-Ghabra, T. H., \& Mamoli, D. (2014). Study the Effect of Adding some. Pharmaceuticals and Chemical Substances on Stability Iron (Ii) In Physiological Media. CHEMISTRY, 1(2), 3039.

Barzał, J. A., Szczylik, C., Rzepecki, P., Jaworska, M., \& zbieta Anuszewska, E. (2014). Plasma citrulline level as a biomarker for cancer therapy-induced small bowel mucosal damage. Acta Biochimica Polonica, 61(4), 61-61. Retrieved from https://dx.doi.org/10 .18388/abp.2014_1823 10.18388/abp.2014_1823

Belsha, D., Bremner, R., \& Thomson, M. (2016). Indications for gastrointestinal endoscopy in childhood. Archives of Disease in Childhood, 101(12), 1153-1160. Retrieved from https://dx.doi.org/10.1136/archdischild-2014-306043 10.1136/archdischild-2014 $-306043$

Bhagatwala, J., Singhal, A., Aldrugh, S., Sherid, M., Sifuentes, H., \& Sridhar, S. (2015). Colonoscopy-indications and contraindications. Screening for Colorectal Cancer with Colonoscopy.

Braicu, C., Cojocneanu-Petric, R., Jurj, A., Gulei, D., Taranu, I., Gras, A. M., Marin, D. E., \& Berindan-Neagoe, I. (2016). Microarray based gene expression analysis of Sus Scrofa duodenum exposed to zearalenone: significance to human health. BMC Genomics, 
17(1), 1-10. Retrieved from https://dx.doi.org/10.1186/s12864-016-2984-8 10 .1186/s12864-016-2984-8

Cappell, M. S. (2008). Reducing the Incidence and Mortality of Colon Cancer: Mass Screening and Colonoscopic Polypectomy. Gastroenterology Clinics of North America, 37(1), 129-160. Retrieved from https://dx.doi.org/10.1016/j.gtc.2007.12.003 10.1016/j.gtc .2007.12.003

Clough, R. E., Waltham, M., Giese, D., Taylor, P. R., \& Schaeffter, T. (2012). A new imaging method for assessment of aortic dissection using four-dimensional phase contrast magnetic resonance imaging. Journal of Vascular Surgery, 55(4), 914-923. Retrieved from https://dx.doi.org/10.1016/j.jvs.2011.11.005 10.1016/j.jvs.2011.11.005

da Silva, B. C., Lyra, A. C., Rocha, R., \& Santana, G. O. (2014). Epidemiology, demographic characteristics and prognostic predictors of ulcerative colitis. World Journal of Gastroenterology, 20(28), 9458-9467. Retrieved from https://dx.doi.org/10.3748/wjg.v20.i28 9458 10.3748/wjg.v20.i28.9458

Dhanwal, D., Dennison, E., Harvey, N., \& Cooper, C. (2011). Epidemiology of hip fracture: Worldwide geographic variation. Indian Journal of Orthopaedics, 45(1), 15-15. Retrieved from https://dx.doi.org/10.4103/0019-5413.73656 10.4103/0019-5413 .73656

E., V., Sridhar, S., \& P., K. (2019). THE HUMAN SIGMOID- A STUDY IN SOUTH INDIAN CADAVERS. Journal of Evolution of Medical and Dental Sciences, 8(13), 1013-1015. Retrieved from https://dx.doi.org/10.14260/jemds/2019/225 10.14260/jemds/2019/225

Favuzza, J., \& Delaney, C. (2013). Techniques and Tips for Lower Endoscopy. In Principles of Flexible Endoscopy for Surgeons (pp. 191-199). Springer.

Fernández, A., Hernández, V., Martínez-Ares, D., Sanromán, L., de Castro, M. L., Pineda, J. R., Carmona, A., González-Portela, C., Salgado, C., Martínez-Cadilla, J., Pereira, S., GarcíaBurriel, J. I., Vázquez, S., \& Rodríguez-Prada, I. (2015). Incidence and phenotype at diagnosis of inflammatory bowel disease. Results in Spain of the EpiCom study. Gastroenterología y Hepatología, 38(9), 534-540. Retrieved from https://dx.doi.org/10.1016/ j.gastrohep.2015.03.001 10.1016/j.gastrohep.2015.03.001

Gerson, L. B., Tokar, J., Chiorean, M., Lo, S., Decker, G. A., Cave, D., BouHaidar, D., Mishkin, D., Dye, C., Haluszka, O., Leighton, J. A., Zfass, A., \& Semrad, C. (2009). Complications Associated With Double Balloon Enteroscopy at Nine US Centers. Clinical Gastroenterology and Hepatology, 7(11), 1177-1182.e3. Retrieved from https://dx.doi.org/10.1016/ j.cgh.2009.07.005 10.1016/j.cgh.2009.07.005

Haggard, S., \& Kaufman, R. R. (2008). Development, democracy, and welfare states: Latin America, East Asia, and eastern Europe.

Hanafy, B. G., Abumandour, M. M. A., \& Bassuoni, N. F. (2020). Morphological features of the gastrointestinal tract of Garganey (Anas querquedula, Linnaeus 1758)-Oesophagus to coprodeum. Anatomia, Histologia, Embryologia, 49(2), 233-250. Retrieved from https://dx.doi.org/10.1111/ahe.12519 10.1111/ahe.12519

Jeong, S. Y., Chung, D. J., Yeo, D. M., Lim, Y. T., Hahn, S. T., \& Lee, J. M. (2013). The usefulness of computed tomographic colonography for evaluation of deep infiltrating endometriosis: comparison with magnetic resonance imaging. Journal of computer assisted tomography, 37(5), 809-814.

Jovanovic, I., Vormbrock, K., Zimmermann, L., Djuranovic, S., Ugljesic, M., Malfertheiner, P., Fry, L. C., \& Mönkemüller, K. (2011). Therapeutic Double-Balloon Enteroscopy: A Binational, Three-Center Experience. Digestive Diseases, 29(s1), 27-31. Retrieved from https://dx.doi.org/10.1159/000331125 10.1159/000331125 
Levin, B., Lieberman, D. A., McFarland, B., Smith, R. A., Brooks, D., Andrews, K. S., Dash, C., Giardiello, F. M., Glick, S., Levin, T. R., Pickhardt, P., Rex, D. K., Thorson, A., \& and, S. J. W. (2008). Screening and Surveillance for the Early Detection of Colorectal Cancer and Adenomatous Polyps, 2008: A Joint Guideline from the American Cancer Society, the US Multi-Society Task Force on Colorectal Cancer, and the American College of Radiology. CA: A Cancer Journal for Clinicians, 58(3), 130-160. Retrieved from https://dx.doi.org/ 10.3322/ca.2007.0018 10.3322/ca.2007.0018

Marín, M., Giner, R. M., Ríos, J.-L., \& Recio, M. C. (2013). Intestinal anti-inflammatory activity of ellagic acid in the acute and chronic dextrane sulfate sodium models of mice colitis. Journal of Ethnopharmacology, 150(3), 925-934. Retrieved from https://dx.doi.org/ 10.1016/j.jep.2013.09.030 10.1016/j.jep.2013.09.030

Molodecky, N. A., Soon, I. S., Rabi, D. M., Ghali, W. A., Ferris, M., Chernoff, G., Benchimol, E. I., Panaccione, R., Ghosh, S., Barkema, H. W., \& Kaplan, G. G. (2012). Increasing Incidence and Prevalence of the Inflammatory Bowel Diseases With Time, Based on Systematic Review. Gastroenterology, 142(1), 46-54.e42. Retrieved from https://dx.doi.org/ 10.1053/j.gastro.2011.10.001 10.1053/j.gastro.2011.10.001

Moulin, D. D. (2012). A short history of breast cancer. Springer Science \& Business Media.

Nasr, A. B., Lakshmi, D. B. V., \& V., D. B. (2015). Phytate Supplementation Modulates Metallothionein-1 Expression in Colon Cancer.

Palmer, M., Bailie, C., Magowan, E., Metzler-Zebeli, B. U., Mahoney, N., Wimmers, K., \& Lennon, A. (2017). Oral communications, invited talks and posters presented at the WPSA UK Branch Meeting held at the University of Chester. These summaries have been edited for clarity and style by the WPSA UK Programme Committee but have not been fully peer-reviewed.

Petrinec, Z., Nejedli, S., Kuzir, S., \& Opacak, A. (2005). Mucosubstances of the digestive tract mucosa in northern pike (Esox lucius L.) and european catfish (Silurus glanis L.). Veterinarski arhiv., 75, 317-317.

Serra-Aracil, X., Gràcia, R., Mora-López, L., Serra-Pla, S., Pallisera-Lloveras, A., Labró, M., \& Navarro-Soto, S. (2019). How to deal with rectal lesions more than $15 \mathrm{~cm}$ from the anal verge through transanal endoscopic microsurgery. The American Journal of Surgery, 217(1), 53-58. Retrieved from https://dx.doi.org/10.1016/j.amjsurg.2018.04.014 10 .1016/j.amjsurg.2018.04.014

Sheen, E., Pan, J., Ho, A., \& Triadafilopoulos, G. (2019). Lower Gastrointestinal Bleeding. Geriatric Gastroenterology, 1-21.

Shivashankar, R., Tremaine, W. J., Harmsen, W. S., \& Loftus, E. V. (1970). Incidence and prevalence of Crohn's disease and ulcerative colitis in Olmsted County. Clinical Gastroenterology and Hepatology, 15(6), 857-863.

Spada, C., Stoker, J., Alarcon, O., Barbaro, F., Bellini, D., Bretthauer, M., Haan, M. D., Dumonceau, J.-M., Ferlitsch, M., Halligan, S., Helbren, E., Hellstrom, M., Kuipers, E., Lefere, P., Mang, T., Neri, E., Petruzziello, L., Plumb, A., Regge, D., ... Laghi, A. (2014). Clinical indications for computed tomographic colonography: European Society of Gastrointestinal Endoscopy (ESGE) and European Society of Gastrointestinal and Abdominal Radiology (ESGAR) Guideline. Endoscopy, 46(10), 897-915. Retrieved from https://dx.doi.org/ 10.1055/s-0034-1378092 10.1055/s-0034-1378092

Valero, M. S., Ramón-Gimenez, M., Lozano-Gerona, J., Delgado-Wicke, P., Calmarza, P., OlivánViguera, A., López, V., Ángel Luis Garcia-Otín, Valero, S., Pueyo, E., Hamilton, K. L., Miura, H., \& Köhler, R. (2019). KCa3.1 Transgene Induction in Murine Intestinal Epithelium Causes Duodenal Chyme Accumulation and Impairs Duodenal Contractility. Inter- 
national Journal of Molecular Sciences, 20(5), 1193-1193. Retrieved from https://dx .doi.org/10.3390/ijms20051193 10.3390/ijms20051193

Welty, M., Mesana, L., Padhiar, A., Naessens, D., Diels, J., van Sanden, S., \& Pacou, M. (2020). Efficacy of ustekinumab vs. advanced therapies for the treatment of moderately to severely active ulcerative colitis: a systematic review and network meta-analysis. Current Medical Research and Opinion, 36(4), 595-606. Retrieved from https://dx.doi.org/10.1080/ 03007995.2020.1716701 10.1080/03007995.2020.1716701

Yano, T., \& Yamamoto, H. (2009). Current state of double balloon endoscopy: The latest approach to small intestinal diseases. Journal of Gastroenterology and Hepatology, 24(2), 185-192. Retrieved from https://dx.doi.org/10.1111/j.1440-1746.2008.05773 .x 10.1111/j.1440-1746.2008.05773.x 